\title{
ANALISIS PENGARUH PROFITABILITAS, LEVERAGE, DAN UKURAN PERUSAHAAN TERHADAP KETEPATAN WAKTU PELAPORAN KEUANGAN
}

\author{
Shinta Kasin \\ Rizka Indri Arfianti* \\ Program Studi Akuntansi, Institut Bisnis dan Informatika Kwik Kian Gie, \\ Jl. Yos Sudarso Kav. 87, Jakarta 14350
}

\begin{abstract}
Timeliness of financial reporting aims to provide information on the financial position, performance, and changes in the company's financial position on time before losing its ability in economic decision-making. The information in the financial statements is said to be useful when available on time when needed. The purpose of this study is to determine the effect of profitability, leverage, and company size on timeliness. The research method used is logistic regression analysis method. The sampling technique used is purposive sampling method. The samples used are 87 manufacturing companies listed on the BEI in 2014-2016 with a total of 261 data. The analysis used in this study using SPSS version 20. The results showed that profitability had a significant positive effect on timeliness at $\alpha=5 \%$ with $p$-value of 0.0275 , leverage did not significantly influence p-value value 0.4995, and firm size also no significant effect on timeliness with p-value of 0.350. The conclusion of this study is that there is sufficient evidence that companies with high profitability tend to be timely in delivering financial statements and there is not enough evidence of companies that have low leverage and small company size tend to be timely in delivering financial statements.
\end{abstract}

Keywords: Timeliness, Profitability, Leverage, Firm Size

\begin{abstract}
Abstrak
Ketepatan waktu pelaporan keuangan bertujuan untuk menyediakan informasi mengenai posisi keuangan, kinerja, serta perubahan posisi keuangan perusahaan tepat waktu sebelum kehilangan kemampuannya dalam pengambilan keputusan ekonomi. Informasi dalam laporan keuangan dikatakan bermanfaat apabila tersedia tepat waktu ketika dibutuhkan. Tujuan dari penelitian ini adalah untuk mengetahui pengaruh profitabilitas, leverage, dan ukuran perusahaan terhadap ketepatan waktu pelaporan keuangan (timeliness). Metode penelitian yang digunakan adalah metode analisis regresi logistik. Teknik pengambilan sampel yang digunakan adalah purposive samplingmethod. Sampel yang digunakan sebanyak 87 perusahaan manufaktur yang terdaftar di BEI pada tahun 2014-2016 dengan jumlah 261 data.Analisis yang digunakan dalam penelitian ini menggunakan bantuan SPSS versi 20. Hasil penelitian menunjukkan bahwa profitabilitas berpengaruh signifikan positif terhadap timeliness pada $\alpha=5 \%$ dengan nilai $p$-value sebesar 0.0275 , leverage tidak berpengaruh signifikan dengan nilai $p$-value sebesar 0.4995 , dan ukuran perusahaan juga tidak berpengaruh signifikan terhadap timeliness dengan nilai p-value sebesar 0.350 . Kesimpulan dari penelitian ini adalahterdapat cukup bukti perusahaan yang memiliki profitabilitas tinggi cenderung tepat waktu dalam menyampaikan laporan keuangan dan tidak terdapat cukup bukti perusahaan yang memilikileverage rendah dan ukuran perusahaan kecil cenderung tepat waktu dalam menyampaikan laporan keuangan.
\end{abstract}

Kata Kunci: Ketepatan Waktu, Profitabilitas, Leverage, Ukuran Perusahaan

\footnotetext{
* Alamat kini:Institut Bisnis dan Informatika Kwik Kian Gie, Jln Yos Sudarso Kav. 87 Sunter , Jakarta 14350 Penulis untuk Korespondensi: Telp. (021) 65307062 Ext. 708. E-mail: rizka.indri@kwikkiangie.ac.id
} 


\section{Pendahuluan}

$\mathrm{P}$ erekonomian di Indonesia terus mengalami perkembangan seiring dengan semakin berkembangnya teknologi informasi. Salah satu tandanya adalah kemunculan banyak perusahaan di pasar modal. Pasar modal merupakan indikator perekonomian negara. Perusahaan yang membutuhkan modal dapat memperoleh modal melalui hutang atau menerbitkan saham ke pasar modal (go public). Aktivitas dan volume penjualan atau pembelian di pasar modal yang semakin meningkat (padat) memberi indikasi bahwa aktivitas bisnis berbagai perusahaan berjalan dengan baik dan begitu pula sebaliknya. Kegiatan bisnis di pasar modal berlangsung sangat kompleks dan memiliki tingkat persaingan yang tinggi, sehingga ketersediaan informasi menjadi hal yang sangat penting dalam setiap pengambilan keputusan. Romney dan Steinbert (2015) menyatakan bahwa karakteristik informasi yang berguna adalah informasi yang relevan, dapat diandalkan, lengkap, tepat waktu, dapat dipahami, dapat diverifikasi dan dapat diakses. Salah satu media yang dapat dijadikan sumber informasi dalam pengambilan keputusan untuk investasi di pasar modal adalah laporan keuangan.

Informasi dalam laporan keuangan dikatakan bermanfaat apabila tersedia tepat waktu ketika dibutuhkan (Suwardjono, 2005). Penyampaikan laporan keuangan kepada publik tidak melewati batas waktu yang telah ditentukan atau tepat pada saat dibutuhkan agar tersedianya informasi dan dapat mempengaruhi proses pengambilan keputusan pengguna laporan keuangan tersebut, seperti investor, kreditor, pemerintah dan lain-lain. Investor memerlukan informasi keuangan untukmendukung keputusan agar dapat melakukan perencanaan dan memaksimalkan utilitas investasinya. Fungsi utilitas bagi investor menunjukkan kemampuan seorang investor untuk mengamati dan memilih terhadap berbagai pilihan investasi dengan masing-masing risiko dan tingkat pengembalian (return). Sementara, kreditor memerlukan informasi dalam laporan keuangan untuk menilai apakah perusahaan akan mampu untuk membayar hutang-hutangnya.

Pada tahun 2017, Bursa Efek Indonesia (BEI) menghentikan sementara perdagangan efek (mensuspensi) di pasar reguler dan tunai terhadap 17 perusahaan tercatat atau emiten pada perdagangan 3 Juli 2017. Suspensi itu dilakukan, mengingat berdasarkan pemantauan manajemen BEI hingga 29 Juni 2017, terdapat 17 perusahaan tercatat yang belum menyampaikan laporan keuangan auditan per 31 Desember 2016. Selain itu, perusahaan-perusahaan tersebut juga belum menyampaikan denda atas keterlambatan penyampaian laporan keuangannya (www.bisnis.liputan6.com).

Menurut Hanum (2012), profitabilitas adalah kemampuan perusahaan dalam mencapai keuntungan dengan meningkatkan efisiensi dan efektivitas kinerja yang dilakukan. Profitabilitas dapat dihitung melalui Return on Asset (ROA) dengan membandingkan antara laba bersih tahun berjalan dengan total aset perusahaan pada tahun tersebut. Profitabilitas juga digunakan untuk menggambarkan seberapa besar penggunaan nilai atas saham yang dimiliki (Return on Equity/ROE). Rasio ini sangat penting karena dapat menentukan apakah laporan keuangan merupakan berita baik atau tidak. Jika profitabilitas perusahaan rendah, maka pihak manajemen perusahaan yang sedang mengalami kesulitan keuangan akan cenderung menunda penyampaian laporan keuangan yang berisi berita buruk (bad news). Begitu pula sebaliknya, semakin tinggi profitabilitas perusahaan maka semakin baik bagi perusahaan karena profitabilitas menunjukkan keberhasilan perusahaan dalam menghasilkan keuntungan sehingga dapat dikatakan bahwa profit merupakan berita baik bagi perusahaan (Lianto dan Kusuma, 2010). Pengujian juga telah dilakukan oleh Prastiwi, Yuniarta, Ari, \& Darmawan (2014), secara parsial profitabilitas (ROA) tidak memiliki 
pengaruh yang signifikan terhadap ketepatan waktu pelaporan keuangan. Namun, dalam penelitian Pande \& Mertha (2016) menunjukkan bahwa profitabilitas memiliki pengaruh negatif terhadap keterlambatan penyampaian laporan keuangan.

Leverage yang tinggi menunjukkan perusahaan memiliki banyak kewajiban atau hutang pada pihak lain. Hutang yang tinggi mengakibatkan resiko keuangan menjadi semakin tinggi karena dikhawatirkan adanya kemungkinan bahwa perusahaan tersebut tidak bisa melunasi kewajiban atau hutangnya baik berupa pokok maupun bunganya. Resiko perusahaan yang tinggi mengindikasikan bahwa perusahaan mengalami kesulitan keuangan. Hal ini merupakan berita buruk yang akan mempengaruhi kondisi perusahaan di mata masyarakat. Pihak manajemen akan cenderung menunda penyampaian laporan keuangan yang berisi berita buruk perusahaan yang sedang mengalami kesulitan keuangan ini sehingga meningkatkan potensi terlambatnya perusahaan menyampaikan laporan keuangan kepada publik. Penelitian yang dilakukan Rachmawati (2008) menunjukkan bahwa variabel leverage yang diproksikan dengan Total Debt to Total Asset Ratio ditemukan berpengaruh secara signifikan. Sedangkan penelitian yang dilakukan oleh Hilmi dan Ali (2008) tidak menemukan pengaruh yang signifikan antara leverage dengan ketepatan waktu pelaporan keuangan.

Besar (ukuran) perusahaan dapat dinyatakan dalam total aktiva, penjualan, dan kapitalisasi pasar. Semakin besar total aktiva, penjualan dan kapitalisasi pasar maka semakin besar pula ukuran perusahaan itu. Semakin besar aktiva maka semakin banyak modal yang ditanam, semakin banyak penjualan maka semakin banyak perputaran uang dan semakin besar kapitalisasi pasar maka semakin besar pula ia dikenal dalam masyarakat. Dari ketiga variabel ini, nilai aktiva relatif lebih stabil dibandingkan dengan nilai market capitalized dan penjualan dalam mengukur ukuran perusahaan (Sudarmadji dan Sularto, 2007). Abdulla (1996) dalam Merdekawati dan Regina (2011)menyatakan bahwa perusahaan besar mempunyai tingkat kompleksitas yang tinggi sehingga proses audit tidak dapat diselesaikan dalam periode yang singkat. Pernyataan tersebut didukung oleh Givoly dan Palmon (1982) dan Hossain dan Taylor (1998)yang mengatakan bahwa perusahaan besar membutuhkan prosedur audit dan pengambilan sampel yang lebih banyak sehingga proses audit tidak dapat diselesaikan dengan cepat. Pernyataan ini juga sesuai dengan hasil penelitian Merdekawati dan Regina (2011)yang menunjukkanadanya pengaruh negatif signifikan antaraukuran perusahaan terhadap ketepatan waktu dalam menyampaikan laporan keuangan, namun dalam penelitian Givoly dan Palmon (1982) dan Handayani dan Wirakusuma (2013) tidak menemukan adanya pengaruh yang signifikan antara ukuran perusahaan terhadap ketepatan waktu pelaporan keuangan.

Penelitian ini bertujuan untuk mencari bukti empiris pengaruhProfitabilitas, Leverage, dan Ukuran Perusahaan terhadap Timeliness. Penelitian ini diharapkan bisa bermanfaat bagi perusahaan untuk mengkaji faktor-faktor yang bisa mempengaruhi ketepatan waktu pelaporan keuangan. Hasil penelitian ini juga bisa bermanfaat sebagai sumber referensi bagi penelitian selanjutnya.

Beberapa kajian teori pendukung yang digunakan peneliti dalam penelitian ini antara lain:

\section{Teori Agensi}

Teori keagenan mendeskripsikan hubungan yang timbul antara principal dengan agent dilandasi karena adanya kontrak, Jensen dan Meckling (1976). Teori diatas juga mengemukakan adanya konflik yang disebabkan perbedaan kepentingan antara principal dengan agent. Berdasarkan uraian diatas, konflik yang timbul antara principal dengan agent dapat mempengaruhi ketepatan waktu pelaporan keuangan yang dilaporkan 
oleh agent. Adanya kepentingan dimana agent akan berusaha memaksimalkan kekayaan pemegang saham membuat agent menggunakan segala cara untuk menunda menyampaikan laporan keuangan sehingga pelaporan keuangan menjadi tidak tepat waktu.

\section{Teori Sinyal}

Menurut Wolk et al. (2001: 101), teori sinyal menjelaskan mengapa perusahaan mempunyai dorongan untuk melaporkan laporan keuangan secara sukarela ditunjukan kepada pasar modal walaupun tidak ada kewajiban untuk melakukan pelaporan, perusahaan bersaing dengan perusahaan lainnya untuk memperkecil risiko dan pengungkapan sukarela dibutuhkan untuk dapat berhasil dalam bersaing di pasar. Teori sinyal dalam akuntansi salah satu fungsinya untuk menilai adanya informasi privat. Informasi privat kadang-kadang mengindikasikan bahwa nilai perusahaan lebih tinggi dari yang terefleksikan dalam harga saham saat ini. Untuk mentransfer informasi manajer dapat men-disclose secara langsung. Namun, pengungkapan eksplisit mungkin berbahaya pada perusahaan dengan alasan kompetitif atau larangan dari klausal perjanjian kerahasiaan perusahaan. Ketika pengungkapan langsung tidak mungkin dilakukan, manajer dapat menggunakan sinyal tertentu bahwa harga saham underpriced (Jaswadi, 2004). Dari penjelasan diatas dapat disimpulkan bahwa teori sinyal merupakan teori yang menyatakan perilaku manajer dalam mengkomunikasikan informasi tentang kondisi perusahaan melalui sinyal dan berkaitan dengan ketepatan waktu pelaporan keuangan, dimana perusahaan yang menyampaikan laporan keuangan secara tepat waktu, dapat dikatakan bahwa perusahaan tersebut memiliki kabar baik (good news). Perusahaan yang memiliki kabar baik cenderung ingin segera menyampaikan kabar baik tersebut kepada publik sehingga harga saham diharapkan meningkat. Sebaliknya, perusahaan yang terlambat menyampaikan laporan keuangannya dapat dikatakan bahwa perusahaan tersebut cenderung menutupi kabar buruk (bad news) kepada publik.

\section{Laporan Keuangan}

Menurut PSAK No. 1 (2012), laporan keuangan adalah suatu penyajian terstruktur dari posisi keuangan dan kinerja keuangan suatu entitas. Tujuan laporan keuangan adalah memberikan informasi mengenai posisi keuangan, kinerja keuangan, dan arus kas entitas yang bermanfaat bagi sebagian besar kalangan pengguna laporan keuangan dalam pembuatan keputusan ekonomi. IASB mengidentifikasi karakteristik kualitatif informasi akuntansi untuk membedakan informasi yang lebih baik (lebih berguna) dan lnformasi yang inferior (kurang bermanfaat) untuk keperluan pembuatan keputusan. Agar informasi keuangan menjadi berguna, informasi tersebut harus relevan (relevance) dan merepresentasi secara tepat apa yang direpresentasikan (faithfulrepresentation). Kegunaan informasi keuangan dapat ditingkatkan jika informasi tersebut dapat diperbandingkan (comparable), terverifikasi (verifiable), tepat waktu (timeliness), dan dapat dipahami (understandability).

\section{Timeliness}

Ketepatwaktuan adalah tersedianya informasi bagi pembuat keputusan pada saat dibutuhkan sebelum informasi tersebut kehilangan kekuatan untuk memengaruhi keputusan(Kieso et al., 2018). Pelaporan keuangan perusahaan publik di Indonesia diatur oleh UU No. 8 tahun 1995 tentang pasar modal. Menurut undang-undang tersebut diterangkan dengan jelas kewajiban untuk menyampaikan dan mengumumkan laporan yang berisi informasi berkala tentang kegiatan usaha dan keadaan keuangan perusahaan publik.Kewajiban ini dimaksudkan juga agar informasi mengenai jalannya usaha perusahaan tersebut selalu tersedia bagi 
masyarakat. Dalam peraturan yang dikeluarkan oleh OJK (Otorisasi Jasa Keuangan), yaitu peraturan No. X.K.6, Lampiran No. KEP-431/BL/2012 tentang penyampaian laporan tahunan emiten atau perusahaan, peraturan tersebut menyebutkan bahwa perusahaan publik yang pernyataan pendaftarannya telah menjadi efektif wajib menyampaikan laporan tahunan kepada OJK (Otorisasi Jasa Keuangan) paling lama 4 bulan setelah tahun buku berakhir. Penyampaian laporan tahunan dimaksud melewati batas waktu penyampaian laporan keuangan tahunan diperhitungkan sebagai keterlambatan penyampaian laporan keuangan tahunan.

\section{Pengaruh Profitabilitas terhadap Timeliness}

Menurut Asnawi dan Wijaya (2015: 26), rasio profitabilitas/laba menunjukkan kemampuan perusahaan mendapatkan hasil selama satu periode produksi. Profitabilitas perusahaan dapat diukur dengan menghitung Return on Asset (ROA), Return on Equity (ROE), Gross Profit Margin, atau bisa juga dengan Net Profit Margin dengan melihat data total aktiva, total ekuitas, total pendapatan atau penjualan dan laba bersih setelah pajak melalui laporan keuangan perusahaan. Menurut Lianto dan Kusuma (2010), profitabilitas menunjukkan keberhasilan perusahaan dalam menghasilkan keuntungan. Sehingga profitabilitas merupakan ukuran penting yang sering dijadikan patokan oleh para investor dalam menilai sehat atau tidaknya suatu perusahaan, yang dapat juga mempengaruhi keputusan untuk membeli atau menjual saham suatu perusahaan. Profitabilitas juga sering digunakan oleh kreditor untuk memutuskan diberikan atau tidak diberikannya pinjaman ditunjukan kepada suatu perusahaan.Setiap perusahaan ingin mendapatkan laba yang tinggi sehingga manajemen akan berusaha mengelola perusahaan secara maksimal untuk menghasilkan laba yang tinggi tersebut.
Profitabilitas yang tinggi menunjukkan bahwa perusahaan tersebut memiliki sistem dan cara kerja yang baik dalam menghasilkan profit.

Profitabilitas yang dihasilkan oleh suatu perusahaan menunjukkan keberhasilan dari perusahaan tersebut dalam menghasilkan keuntungan. Tinggi atau rendahnya profitabilitas suatu perusahaan dapat berpengaruh atau tidak berpengaruh terhadap ketidaktepatwaktuan publikasi laporan keuangan. Perusahaan yang memiliki profitabilitas tinggi akan memberikan sinyal baik kepada publik, dengan cenderung segera menyampaikan laporan keuangan tepat waktu, sehingga publik akan melihat bahwa manajemen berhasil dalam mengelola perusahaan tersebut dan laporan keuangan dalam keadaan yang sehat. Jika yang dilaporkan adalah berita buruk maka perusahaan cenderung lebih lama melaporkan laporan keuangannya karena perusahaan ingin menutupi bad news ini sehingga publik tidak mengetahui mengenai berita tersebut. Dengan demikian, dapat disimpulkan bahwa pengaruh profitabilitas terhadap timeliness adalah positif dimana perusahaan yang memiliki profitabilitas tinggi, cenderung lebih tepat waktu dalam menyampaikan laporan keuangan.

Ha1 : Perusahaan yang memiliki profitabilitas tinggi cenderung lebih tepat waktu dalam menyampaikan laporan keuangan.

\section{Pengaruh Leverage terhadap Timeliness}

Menurut Asnawi dan Wijaya (2015), leverage (solvabilitas) menunjukkan kemampuan bayar untuk jangka panjang. Dengan kata lain, leverage digunakan untuk mengetahui seberapa jauh suatu perusahaan bergantung pada hutang dalam membiayai aktiva atau ekuitas perusahaan. Bagi investor, leverage dapat menunjukkan kemampuan perusahaan dalam memenuhi kewajiban jangka panjang. Sehingga merupakan tanggung jawab bagi manajemen untuk mengelola perusahaan dan meminimalisir 
resiko dengan memastikan bahwa perusahaan tidak memiliki aktiva yang dibiayai oleh hutang dalam jumlah besar. Menurut Respati (2004), tingginya leverage mencerminkan tingginya resiko keuangan perusahaan. Tingginya resiko ini menunjukkan adanya kemungkinan bahwa perusahaan tersebut tidak bisa melunasi kewajiban atau hutangnya baik berupa pokok maupun bunganya. Resiko perusahaan yang tinggi mengindikasikan bahwa perusahaan mengalami kesulitan keuangan, kesulitan keuangan merupakan berita buruk yang akan mempengaruhi kondisi perusahaan di mata masyarakat. Pihak manajemen perusahaan yang sedang mengalami kesulitan keuangan akan cenderung menunda penyampaian laporan keuangan yang berisi berita buruk.

Perusahaan yang memiliki leverage rendah adalah perusahaan yang mampu membayar kewajiban perusahaan pada suatu periode. Apabila perusahaan memiliki kemampuan membayar hutang tinggi, dapat diasumsikan perusahaan tersebut memiliki keuangan yang sehat karena aktiva yang dimiliki perusahaan lebih besar dibandingkan dengan kewajiban yang harus dikeluarkan perusahaan tersebut. Jika perusahaan memiliki kewajiban atau hutang yang tinggi maka perusahaan tersebut akan menunda untuk mempublikasikan laporan keuangan karena hal ini merupakan bad news. Sebaliknya, jika perusahaan mempunyai kewajiban atau hutang yang rendah maka perusahaan akan cenderung cepat menyampaikan laporan keuangannya kepada publik karena menunjukkan laporan keuangan dalam keadaan yang sehat dan baik (good news) sehingga publikasi laporan keuangan tepat waktu. Dari penjelasan diatas dapat disimpulkan bahwa leverage berpengaruh negatif terhadap timeliness. Dimana semakin rendah leverage, maka perusahaan cenderung lebih tepat waktu dalam menyampaikan laporan keuangan.

Ha2 : Perusahaan yang memiliki leverage rendah cenderung lebih tepat waktu dalam menyampaikan laporan keuangan.

\section{PengaruhUkuran Perusahaan terhadap Timeliness}

Ukuran perusahaan merupakan salah satu faktor yang berpengaruh terhadap timeliness. Besar kecilnya ukuran perusahaan juga dipengaruhi oleh kompleksitas operasional, variabel dan intensitas transaksi perusahaan. Menurut Sudarmadji dan Sularto (2007) ukuran perusahaan dapat dinilai dari beberapa segi, antara lain total nilai aktiva, total penjualan dan kapitalisasi pasar. Semakin besar nilai item-item tersebut maka semakin besar pula ukuran perusahaan itu. Semakin besar aktiva maka semakin banyak modal yang ditanam, semakin banyak penjualan maka semakin banyak perputaran uang dan semakin besar kapitalisasi pasar maka semakin besar pula perusahaan tersebut dikenal dalam masyarakat. Ukuran perusahaan menunjukkan seberapa besar informasi yang terkandung didalam perusahaan tersebut. Merdekawati dan Regina (2011) dalam penelitian mereka menemukan bahwa ukuran perusahaan secara signifikan mempunyai hubungan dengan ketepatan waktu penyampaian laporan keuangan. Variabel yang mereka gunakan untuk untuk mengukur hubungan antara ukuran perusahaan dan timeliness adalah total aset. Mereka berpendapat bahwa perusahaan yang memiliki sumber daya (aset) yang besar membutuhkan prosedur audit dan pengambilan sampel yang lebih banyak sehingga proses audit tidak dapat diselesaikan dengan cepat. Hal ini memungkinkan perusahaan dengan ukuran yang besar dalam melaporkan laporan keuangan auditannya ke publik lebih lambat dibandingkan dengan perusahaan yang lebih kecil.

Ukuran perusahaan dapat dilihat dari total kekayaan atau total aset yang dimiliki perusahaan. Perusahaan besar mempunyai tingkat kompleksitas yang tinggi sehingga proses audit tidak dapat diselesaikan dalam 
periode yang singkat. Auditor membutuhkan prosedur audit dan pengambilan sampel yang lebih banyak dalam menyelesaikan proses auditnya, sehingga penyampaian laporan keuangan kepada publik menjadi terlambat. Dari penjelasan diatas dapat disimpulkan bahwa ukuran perusahaan berpengaruh negatif terhadap timeliness. Dimana semakin kecil ukuran perusahaan, maka perusahaan cenderung lebih tepat waktu dalam menyampaikan laporan keuangan.

Ha3 : Perusahaan yang memiliki ukuran perusahaan kecil cenderung lebih tepat waktu dalam menyampaikan laporan keuangan.

\section{Metode Penelitian}

Objek penelitian yang digunakan didalam penelitian ini adalah laporan keuangan auditan perusahaan-perusahaan manufaktur yang sahamnya terdaftar dan di perdagangkan di Bursa Efek Indonesia (BEI) (www.idx.co.id) serta terdapat didalam Indonesian Capital Market Directory(ICMD) pada tahun 20142016.

\section{Variabel Penelitian}

\section{Timeliness}

Timelinessdiukur berdasarkan tanggal penyampaian laporan keuangan tahunan auditan ke Bapepam. Sesuai dengan peraturan paling baru yang dikeluarkan oleh OJK (Otorisasi Jasa Keuangan), yaitu peraturan No X.K.6, Lampiran No. KEP-431/BL/2012 tentang penyampaian laporan tahunan emiten atau perusahaan, perusahaan publik yang pernyataan pendaftarannya telah menjadi efektif wajib menyampaikan laporan tahunan kepada OJK (Otorisasi Jasa Keuangan) paling lama 4 bulan setelah tahun buku berakhir. Variabel timeliness dalam penelitian ini diukur dengan menggunakan variabel dummy dengan kategorinya adalah bagi perusahaan yang tepat waktu ( $₫ 20$ hari) masuk kategori 1 dan perusahaan yang terlambat (>120 hari) masuk kategori 0 .

\section{Profitabilitas}

Rasio profitabilitas atau laba
menunjukkan kemampuan perusahaan
menghasilkan laba selama satu periode
produksi. Pada penelitian ini, peneliti
menggunakan ROA sebagai indikator dalam
meneliti profitabilitas, karena ROA
menunjukkan laba bagi perusahaan.Rumus
dari ROAmenurut Asnawi dan Wijaya (2015:
27) adalah:

Keturn on Assets $($ ROA $)=\frac{\text { Earning After } \text { Tax }(E A T)}{\text { Total Aktiva }(\text { Total } \text { Asset })}$

\section{Leverage}

Leverage menunjukkan kemampuan perusahaan dalam memenuhi kewajiban atau hutangnya dengan menggunakan aset yang dimiliki oleh perusahaan. Pada penelitian ini, peneliti menggunakan Debt Ratio (DR) sebagai indikator dalam meneliti leverage, yaitu dengan membagi total kewajiban (total liability) dengan total aset (total asset).Rumus dari Debt Ratio (DR) menurut Asnawi dan Wijaya (2015: 24) adalah:

$$
\text { Debt Ratio }(\mathrm{DR})=\frac{\text { Utang Total }}{\text { Aset Total }}
$$

\section{Ukuran Perusahaan}

Ukuran perusahaan menunjukkan besar atau kecilnya perusahaan yang dapat diukur dengan menggunakan total asset, banyaknya karyawan yang bekerja, nilai pasar saham lain, dan lain-lain. Penelitian ini menggunakan total aset pada laporan keuangan akhir periode perusahaan yang telah diaudit dalam mengukur ukuran perusahaan. Pendekatan atas ukuran perusahaan menggunakan total aset. Karena total aset perusahaan bernilai besar maka hal ini dapat disederhanakan dengan mentranformasikan ke dalam logaritma natural. Rumus dari ukuran perusahaan tersebut adalah:

$$
\mathrm{SIZH}=\mathrm{LN}(\text { Total Asset })
$$




\section{Teknik Pengumpulan Data}

Teknik pengumpulan data yang digunakan dalam penelitian ini adalah teknik observasi dengan pengamatan terhadap data sekunder. Data sekunder adalah sebagai berikut :

1. Data mengenai laporan keuangan audited perusahaan manufaktur yang terdaftar di Bursa Efek Indonesia tahun 2014-2016.

2. Data yang berhubungan dengan sampel perusahaan diperoleh dari website Bursa Efek Indonesia (BEI) yaitu www.idx.co.id.

\section{Teknik Pengambilan Sampel}

Teknik pengambilan sampel yang digunakan adalah non probability sampling yaitu metode purposive sampling dengan tipe judgement sampling. Sampel yang dipilih adalah sampel yang dapat mewakili populasi dengan kriteria-kriteria sebagai berikut.

1. Perusahaan sampel yang digunakan adalah perusahaan manufaktur yang terdaftar di Bursa Efek Indonesia (BEI) pada tahun 2014 sampai dengan 2016 yang sesuai dengan fact book IDX tahun 2014.

2. Perusahaan manufaktur yang menerbitkan laporan keuangan yang telah diaudit oleh auditor independen pada tahun 2014-2016.

3. Perusahaan menggunakan mata uang Rupiah dalam laporan keuangan.

4. Tahun buku perusahaan adalah 31 Desember.

5. Perusahaan tidak di-delisting selama periode penelitian.

6. Perusahaan listing sebelum 1 Januari 2014.

7. Memiliki data yang lengkap mengenai profitabilitas, leverage, ukuran perusahaan, dan timeliness selama periode 2014-2016.

Setelah dilakukan pembatasan populasi, sampel perusahaan yang terpilih sebanyak 87 perusahaan. Sehingga total sampel untuk pengujian periode 3 tahun sebanyak 261 sampel.

\section{Teknik Analisis Data}

Dalam penelitian ini peneliti menggunakan teknik analisis data berupa analisis regresi logistic (logistic regression). Adapun tahapan-tahapan dalam pengujian dengan menggunakan teknik analisis regresi logistic (logistic regression) dapat dijelaskan sebagai berikut:

1. Uji Statistik deskriptif

Statistik deskriptif memberikan gambaran atau deskripsi suatu data yang dilihat dari nilai rata-rata (mean), standar deviasi,

varian, maksimum, minimum,sum,range, kurtosis, danskewness (kemencengan distribusi) (Ghozali2016: 19). Pengukuranyang digunakan dalam penelitian ini adalah nilai minimum,nilai maksimum, dan nilai rata-rata (mean).

2. Uji Kesamaan Koefisien

Uji kesamaan koefisien dilakukan untuk mengetahui apakah pooling data (penggabungan data cross sectional dengan time series) dapat dilakukan. Pengujian ini dilakukan untuk mengetahui apakah ada perbedaan intercept, slope, atau keduanya diantara persamaan regresi yang ada. Pengujian ini dilakukan dengan membentuk dummy tahun.

Kriteria pengambilan keputusan atas uji kesamaan koefisien adalah sebagai berikut:

a. Jika sig dummy tahun >0,05 maka tidak terdapat perbedaaan koefisien dan terima $\mathrm{H}_{0}$, yang berarti pooling data dapat dilakukan.

b. Jika sig dummy tahun <0,05 maka terdapat perbedaan koefisien dan tolak $\mathrm{H}_{0}$ yang berarti pooling data tidak dapat dilakukan.

3. Menilai Keseluruhan Model (Overall Model Fit)

Ghozali (2016: 328) menyatakan bahwa dalam menilai overall fit model terhadap data, terdapat beberapa test 
statistik yang diberikan untuk menilai hal ini. Hipotesis untuk menilai model fit adalah:

$\mathrm{H}_{0}$ : Model yang dihipotesakan fit dengan data

$\mathrm{H}_{\mathrm{a}}$ : Model yang dihipotesakan tidak fit dengan data

Dari hipotesis ini jelas bahwa kita tidak akan menolak hipotesa nol agar supaya model fit dengan data. Statistik yang digunakan berdasarkan pada fungsi likelihood. Likelihood L dari model adalah probabililtas bahwa model yang dihipotesakan menggambarkan data input. Untuk menguji hipotesis nol dan alternatif, L ditransformasikan menjadi 2LogL. Penurunan likelihood (-2LogL) menunjukkan model regresi yang lebih baik atau dengan kata lain model yang dihipotesiskan fit dengan data.

4. Koefisien Determinasi (Nagelkerke's $R$ square)

Cox dan Snell R Square merupakan ukuran yang mencoba meniru ukuran $\mathrm{R}^{2}$ pada multipleregression yang didasarkan pada teknik estimasi likelihood dengan nilai maksimum kurang dari 1(satu) sehingga sulit diinterpretasikan. Nagelkerke's $\mathrm{R}$ square merupakan modifikasi dari koefisien Cox dan Snell untuk memastikan bahwa nilainya bervariasi dari 0 (nol) sampai 1 (satu). Hal ini dilakukan dengan cara membagi nilai Cox dan Snell's $\mathrm{R}^{2}$ dengan nilai maksimumnya. Nilai nagelkerke's $\mathrm{R}^{2}$ dapat diinterpretasikan seperti nilai $\mathrm{R}^{2}$ pada multiple regression. Nilai yang mendekati satu berarti variabel-variabel independen mernberikan hampir semua informasi yang dibutuhkan untuk memprediksi variasi variabel dependen (Ghozali 2016: 329).

5. Menguji Kelayakan Model Regresi

Ghozali (2016: 329) menyatakan bahwa kelayakan model regresi dinilai dengan menggunakan Hosmer and Lemeshow's Goodness of Fit Test.
Hosmer and Lemeshow's Goodness of Fit Test menguji hipotesis nol bahwa data empiris cocok atau sesuai dengan model (tidak ada perbedaan antara model dengan data sehingga model dapat dikatakan fit). Jika nilai Hosmer and Lemeshow's Goodness of Fit Test sama dengan atau kurang dari 0.05, maka hipotesis nol ditolak yang berarti ada perbedaan signifikan antara model dengan nilai observasinya sehingga Goodness fit model tidak baik karena model tidak dapat memprediksi nilai observasinya. Jika nilai Hosmer and Lemeshow's Goodness of Fit Test lebih besar dari 0.05, maka hipotesis nol tidak dapat ditolak dan berarti model mampu memprediksi nilai observasinya atau dapat dikatakan model dapat diterima karena cocok dengan data observasinya.

\section{Tabel Klasifikasi $2 \times 2$}

Tabel klasifikasi 2 × 2 menghitung nilai estimasi yang benar (correct) dan salah (incorrect). Pada kolom merupakan dua nilai prediksi dari variabel dependen dan hal ini sukses (1) dan tidak sukses (0), sedangkan pada baris menunjukkan nilai sesungguhnya dari variabel dependen sukses (1) dan tidak sukses (0). Pada model yang sempurna, maka semua kasus akan berada pada diagonal dengan tingkat ketepatan peramalan $100 \%$. Jika model logistik mempunyai homoskedastisitas, maka presentase yang benar (correct) akan sama untuk kedua baris (Ghozali 2016).

7. Model Regresi Logistik Yang Terbentuk

Analisis yang digunakan dalam penelitian ini merupakan analisis regresi logistik (logistic regression) untuk melihat pengaruh profitabilitas, leverage dan ukuran perusahaan terhadap timeliness. Adapun model regresi dalam penelitian ini sebagai berikut: 
$\ln \frac{p}{(1-p)}=\beta_{0}+\beta_{1}$ YKU $+\beta_{2} L E V+\beta_{3} \operatorname{SIZE}+\varepsilon$

Keterangan:

In $\frac{p}{(1-p)} \quad$ : Nilai rasio kemungkinan perusahaan melaporkan laporan keuangan tepat waktu.

$\beta_{0} \quad$ : Konstanta

$\beta_{1-3} \quad$ : Koefisien

PRO : Profitabilitas

LEV : Leverage

SIZE : Ukuran Perusahaan

Beberapa hal yang perlu diperhatikan dalam pengujian hipotesis adalah:

a. Tingkat signifikan $(\alpha)$ yang digunakan sebesar 5\%.

b. $\mathrm{H}_{0}$ : Variabel independen tidak terdapat cukup bukti berpengaruh terhadap variabel dependen.

$\mathrm{H}_{\mathrm{a}}$ : Variabel independen terdapat cukup bukti berpengaruh terhadap variabel dependen.

c. Membuat kesimpulan yang merupakan penetapan keputusan dalam hal terima atau tidak terima $\mathrm{H}_{\mathrm{a}}$ dengan kriteria pengujian.

\section{Hasil Dan Pembahasan}

\section{Uji Statistik Deskriptif}

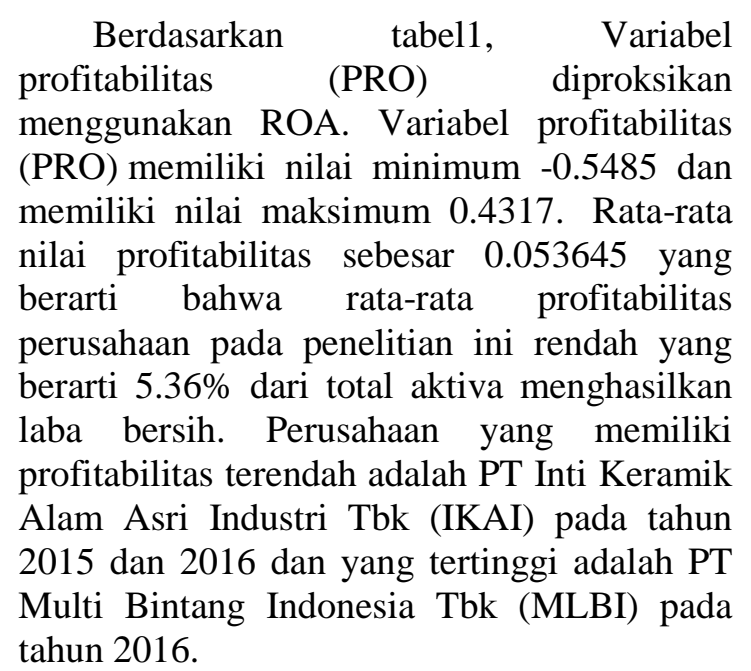

Variabel leverage (LEV) diproksikan menggunakan debtratio. Variabel leverage memiliki nilai minimum 0.0413 dan nilai maksimum 3.0291. Pada penelitian ini, leverage yang mengukur seberapa jauh suatu perusahaan bergantung pada hutang dalam membiayai aktivanya memiliki rata-rata 0.504741 . Hasil tersebut menunjukkan bahwa rata-rata leverage pada perusahaan pada penelitian ini lumayan tinggi yang berarti $50.47 \%$ dari total aktiva dibiayai oleh hutang. Perusahaan yang memiliki leverage terendah adalah PT Jaya Pari Steel Tbk (JPRS) pada tahun 2014 dan yang tertinggi adalah PT Primarindo Asia Infrastructure Tbk (BIMA) pada tahun 2015.

Variabel ukuran perusahaan (SIZE) diproksikan dengan logaritma natural total aset perusahaan. Variabel ukuran perusahaan memiliki nilai minimum 22.3081 dan nilai maksimum 33.1988 serta rata-rata 28.186992. Hal ini mengindikasikan bahwa rata-rata perusahaan manufaktur di Indonesia cenderung kategori perusahaan besar. Perusahaan dengan ukuran perusahaan yang terendah adalah PT Pan Asia Indosyntec Tbk (HDTX) pada tahun 2015 sedangkan yang terbesar adalah PT Astra Internasional Tbk (ASII) pada tahun 2014, 2015 dan 2016.

Pada tabel2, sampel perusahaan yang menyampaikan laporan keuangan tepat waktu sebanyak 243 sampel data perusahaan. Artinya, sudah banyak perusahaan yang menyampaikan laporan keuangannya tepat waktu. Penyampaian yang tepat waktu ini 
sehubungan dengan peraturan OJK No.29/POJK.04/2016 yang mewajibkan perusahaan publik untuk menyampaikan laporan tahunan paling lambat diakhir bulan keempat (120 hari). Walaupun sudah diwajibkan, masih ada perusahaan yang tidak menyampaikan laporan keuangannya tepat waktu. Hal ini dapat dilihat dari perusahaan yang diteliti, yakni ada 18 sampel perusahaan yang terlambat dalam menyampaikan laporan keuangannya. PT Kertas Basuki Rachmat Indonesia Tbk (KBRI) adalah perusahaan yang paling terlambat dalam menyampaikan laporan keuangannya pada tahun 2016. Sementara perusahaan yang paling cepat dalam menyampaikan laporan keuangannya adalah PT Semen Gresik Tbk (SMGR) pada tahun 2015.

\section{Uji Kesamaan Koefisien (pooling)}

Pada tabel3, menunjukkan hasil bahwa seluruh variabel dummy tahun memiliki nilai signifikan diatas 0.05 . Hasil ini menunjukkan bahwa tidak terdapat perbedaan koefisien yang berarti sehingga pooling data dapat dilakukan.

\section{Menilai Keseluruhan Model (Overall Model Fit)}

Pada tabel4 menunjukkan nilai -2 LogL awal adalah sebesar 145.708. Namun setelah dimasukkan ketiga variabel independen, maka nilai -2 $\log \mathrm{L}$ akhir mengalami penurunan menjadi sebesar 126.068. Penurunan nilai2LogL menunjukkan bahwa penambahan variabel independen profitabilitas, leverage, dan ukuran perusahaan ke dalam model memperbaiki model fit dan menunjukkan model regresi logistik yang lebih baik atau dengan kata lain model yang dihipotesiskan fit dengan data sehingga model regresi layak untuk pengujian selanjutnya.

\section{Koefisien Determinasi (Nagelkerke's R Square)}

\begin{abstract}
Pada tabel5 menunjukkan nilai Nagelkerke's $R$ Square sebesar 0,047 yang berarti variabilitas ketepatan waktu penyampaian laporan keuangan(variabel dependen) dapat dijelaskan oleh variabel independen (profitabilitas, leverage, ukuran perusahaan) sebesar $4.7 \%$. Sedangkan sisanya sebesar $95.3 \%$ dijelaskan oleh variabel-variabel lain diluar model penelitian.
\end{abstract}

\section{Menguji Kelayakan Model Regresi}

Pada tabel 6 menunjukkan nilai goodness of fit test yang diukur dengan Chi-Square sebesar 0.674 dimana nilai signifikasi ini jauh diatas 0.05. Maka hal ini dapat dinyatakan bahwa hipotesis nol tidak dapat ditolak, yang berarti hasil penelitian ini mampu memprediksi nilai observasinya atau dapat dikatakan model dapat diterima karena fit dengan data observasinya.

\section{Tabel Klasifikasi 2 × 2}

Matriks klasifikasi pada tabel 7 menunjukkan kekuatan prediksi dari model regresi untuk memprediksi kemungkinan perusahaan menyampaikan laporan keuangannya tepat waktu, yaitu sebesar 99.6\%. Hal ini menunjukkan bahwa dengan menggunakan model regresi terdapat sebanyak 242 perusahaan( $99.6 \%$ ) yang diprediksi akan menyampaikan laporan keuangannya tepat waktu dari total 243 perusahaan yang menyampaikan laporan keuangannya tepat waktu. Kekuatan prediksi model perusahaan yang tidak menyampaikan laporan keuangannya tepat waktu adalah sebesar $0 \%$, yang berarti bahwa model regresi yang digunakan tidak terdapat perusahaan $(0 \%)$ yang tidak menyampaikan laporan keuangannya tepat waktu dari total 18 perusahaan yang tidak menyampaikan laporan keuangannya tepat waktu. Ketepatan klasifikasi secara keseluruhan adalah sebesar 92.7\%. 


\section{Model Regresi Logistik yang Terbentuk}

Pada tabel 8 menunjukkan hasil uji regresi logistik dengan tingkat signifikansi 5\%. Dari tabel 4.8 dapat dilihat bahwa variabel profitabilitas (PRO) memiliki nilai signifikansi sebesar $0.0275(0.055 / 2)$. Nilai signifikansi ini lebih kecil dari 0.05 yang berarti bahwa variabel profitabilitas (PRO) memiliki cukup bukti berpengaruh terhadap timeliness (tidak tolak $\mathrm{H}_{1}$ ). Pengujian terhadap variabel leverage (LEV) memiliki nilai signifikansi sebesar 0.4995 (0.999/2).
Nilai signifikansi ini lebih besar dari 0.05 yang berarti variabel leverage (LEV) tidak memiliki cukup bukti berpengaruh terhadap timeliness (tolak $\mathrm{H}_{2}$ ). Pengujian terhadap variabel ukuran perusahaan (SIZE) memiliki nilai signifikansi sebesar $0.350 \quad(0.700 / 2)$. Nilai ini jauh diatas 0.05 yang berarti variabel ukuran perusahaan (SIZE) tidak memiliki cukup bukti berpengaruh terhadap timeliness $\left(\right.$ tolakH $\left.H_{3}\right)$. Hasil dari pengolahan data ini menghasilkan model sebagai berikut:

$$
\ln \frac{P}{(1-P)}=0.682+4.824 \mathrm{PKO}+0.001 \mathrm{LEV}+0.063 \mathrm{SILE}+\mathrm{\epsilon}
$$

\section{Pembahasan}

\section{Pengaruh Timeliness \\ Profitabilitas terhadap}

Berdasarkan hasil dari analisis regresi logistik, profitabilitas memiliki nilai sebesar 4.824 dan nilai p-value sebesar 0.0275 $(0.055 / 2)$. Hasil pengujian menunjukkan bahwa profitabilitas berpengaruh signifikan positif terhadap timeliness.Sesuai dengan teori sinyal, perusahaan yang memiliki kabar baik(good news) cenderung ingin segera menyampaikan kabar baik tersebut kepada publik dan manajemen dianggap berhasil dalam mengelola perusahaan tersebut, sehingga harga saham diharapkan meningkat.

Dengan demikian, perusahaan yang mempunyai kabar baik akan menyampaikan laporan keuangannya lebih tepat waktu dibandingkan perusahaan yang mempunyai kabar buruk.

Hal ini juga dibuktikan dengan adanya data PT Semen Gresik Tbk (SMGR) yang menyampaikan laporan keuangan tercepat pada tahun 2015 memiliki profitabilitas yang juga cukup tinggi. Begitu pula sebaliknya, PT Kertas Basuki Rachmat Indonesia Tbk (KBRI) yang menyampaikan laporan keuangan paling tidak tepat waktu pada tahun 2016, diketahui memiliki profitabilitas yang cukup rendah. Berarti hipotesis satu yang menyatakan bahwa perusahaan yang profitabilitasnya tinggi cenderung lebih tepat waktu dalam menyampaikan laporan keuangan dapat diterima.

Hasil penelitian ini konsisten dengan hasil penelitian yang dilakukan oleh Andriana dan Raspati (2015) yang menunjukkan bahwa perusahaan yang memperoleh laba cenderung tepat waktu menyampaikan laporan keuangannya dan sebaliknya jika mengalami rugi. Serta penelitian juga dilakukan oleh Carslaw \& Kaplan (2012) yang menemukan bahwa perusahaan yang mengalami kerugian meminta auditornya untuk menjadwalkan pengauditannya lebih lambat dari yang seharusnya, sehingga penyampaian laporan keuangannya terlambat.

\section{Pengaruh Leverage terhadap Timeliness}

Berdasarkan hasil dari analisis regresi logistik, leverage memiliki nilai sebesar 0.001 dan nilai p-value sebesar 0.4995 (0.999/2). Arah hubungan antara leverage dengan timeliness adalah positif, namun tidak berpengaruh signifikan. Sehingga hipotesis dua yang menyatakan leverage berpengaruh signifikan negatif terhadap timeliness ditolak. Hal ini dibuktikan dengan adanya PT Jaya Pari Steel Tbk (JPRS) yang memiliki leverage terendah pada tahun 2014, namun tetap 
menyampaikan laporan keuangannya tepat waktu dan juga PT Primarindo Asia Infrastructure Tbk (BIMA) yang memiliki leverage tertinggi pada tahun 2015, menyampaikan laporan keuangannya tepat waktu juga.

Menurut Abdullah (2006) dalam Hilmi dan Ali (2008), leverage keuangan tidak mempunyai pengaruh terhadap ketepatan waktu penyampaian laporan keuangan. Perusahaan yang sedang mengalami kesulitan keuangan belum tentu cenderung menunda penyampaian laporan keuangannyameski berisi berita buruk. Adanya tuntutan dari pihak lain seperti investor dan kreditor yang melakukan pengawasan membuat perusahaan tetap menyampaikan laporan keuangannya meski tidak sesuai yang diharapkan. Kemudian adanya auditor yang ingin menyelesaikan laporan keuangan tepat waktu sesuai peraturan OJK dapat membuat laporan keuangan tetap tepat waktu untuk dipublikasikan.

\section{PengaruhUkuran Perusahaan terhadap Timeliness}

Berdasarkan hasil dari analisis regresi logistik, ukuran perusahaan memiliki nilai sebesar 0.063 dan nilai $p$-value sebesar 0.350 (0.700/2). Arah hubungan antara ukuran perusahaan dengan timeliness adalah positif, namun tidak berpengaruh signifikan. Hal tersebut menunjukkan bahwa hipotesis tiga yang menyatakan ukuran perusahaan berpengaruh signifikan negatif terhadap timeliness ditolak.

Hal ini dapat dibuktikan dengan adanya data PT Astra International Tbk yang merupakan perusahaan dengan ukuran perusahaan terbesar dilihat dari logaritma natural total aktiva selama tahun 2014, 2015 dan 2016, selalu menyampaikan laporan keuangan tepat waktu. Begitu pula dengan PT Pan Asia Indosyntec Tbk (HDTX), meski merupakan perusahaan dengan ukuran terkecil pada tahun 2015, perusahaan ini tetap menyampaikan laporan keuangannya tepat waktu. Hasil ini sesuai dengan penelitian Respati (2013), dimana disebutkan bahwa variabel ukuran perusahaan tidak dapat menentukan ketepatan waktu perusahaan untuk menyampaikan laporan keuangannya.

Hasil penelitianyang tidak berpengaruh signifikan ini bisa terjadi karena operasi dari seluruh perusahaan manufaktur telah mendapat pengawasan dari Bapepam, sehingga perusahaan manufaktur besar maupun kecil telah memiliki struktur pengendalian internal yang cukup baik. Dengan demikian, perlakuan terhadap setiap perusahaan relatif sama. Selain itu, adanya peraturan paling baru yang dikeluarkan oleh OJK, yaitu peraturan No. X.K.6, Lampiran No. KEP431/BL/2012 tentang penyampaian laporan tahunan paling lama 4 bulan setelah tahun buku berakhir memberikan tambahan waktu bagi perusahaan untuk menyampaikan laporan keuangannya agar tidak melewati batas waktu dan meminimalisir terlambatnya perusahaan yang berukuran besar maupun kecil dalam menyampaikan laporan keuangannya.

\section{Simpulan Dan Saran}

Berdasarkan hasil penelitian dapat diambil kesimpulan bahwa terdapat cukup bukti perusahaan yang profitabilitasnya tinggi cenderung lebih tepat waktu dalam menyampaikan laporan keuangan.Namun tidak terdapat cukup bukti bahwa perusahaan yang leverage-nya rendah cenderung lebih tepat waktu dalam menyampaikan laporan keuangan dan perusahaan yang ukuran perusahaannya kecil cenderung lebih tepat waktu dalam menyampaikan laporan keuangan.

Adapun beberapa saran yang dapat penulis berikan bagi perusahaan-perusahaan yaitu agar perusahaan-perusahaan dapat menyampaikan laporan keuangannya tepat waktu dan juga memperhatikan faktor-faktor yang mempengaruhi ketepatan waktu pelaporan keuangan (timeliness) ters- 
ebut, karena laporan keuangan yang tepat waktu menunjukkan bahwa perusahaan sedang dalam keadaan yang baik.

Bagi investor dan calon investor dapat mempertimbangkan keputusan investasi tidak hanya berdasarkan ketepatan waktu pelaporan keuangan perusahaan tetapi juga pertimbangkan faktor-faktor lain, seperti kinerja perusahaan, tingkat pengembalian, dan lainlain, karena tepat atau tidak tepatnya perusahaan melaporkan laporan keuangannya belum cukup untuk menggambarkan keadaan perusahaan yang sebenarnya.

Bagi penelitian selanjutnya disarankan dapat menambah periode pengamatan yang lebih panjang sehingga dapat diketahui apakah hasil yang diperoleh konsisten dari tahun ke tahun dan diharapkan lebih akurat, menggunakan variabel-variabel lain yang mempengaruhi timeliness selain variabel pada penelitian ini, seperti manajemen laba, likuiditas, umur perusahaan, ukuran KAP, dan lain-lain, serta menggunakan proksi atau ukuran lainnya dalam mengukur variabel profitabilitas, seperti Return on Equity (ROE), Gross Profit Margin dan Net Profit Margin, kemudian Leverage, seperti Debt to Equity (DER), Times Interest Earned Ratio, Fixed Charge Coverage, dan Debt Service Coverage, sertaukuran perusahaan, seperti total pendapatan atau penjualan, marketcapitalization, dan jumlah karyawan.

\section{Daftar Pustaka}

Andriana, Denny \& Nada Arina Raspati, Pengaruh Profitabilitas dan Kepemilikan Publik terhadap Ketepatan Waktu Penyampaian Laporan Keuangan, Jurnal Riset dan Akuntansi Keuangan, 3 (2), 2015 , 675-687

Asnawi, S. K. \& WIjaya, C. 2015, FINON (Finance for Non Finance), Jakarta: PT Raja Grafindo Persada
Bursa Efek Indonesia 2014. Indonesian Capital Market Directory 2014, Jakarta: Bursa Efek Indonesia.

Bursa Efek Indonesia. 2015. Indonesian Capital Market Directory 2015, Jakarta: Bursa Efek Indonesia.

Bursa Efek Indonesia. 2016. Indonesian Capital Market Directory 2016, Jakarta: Bursa Efek Indonesia.

Carslaw, C. A. P. N., \& Kaplan, S. E. 2012. An Examination of Audit Delay: Further Evidence from New Zealand An Examination of Audit Delay: Further Evidence from New Zealand *, (December), 37-41.

Dyer, J. C., \& McHugh, A. J. 1975. The Timeliness of the Australian Annual Report. Journal of Accounting Research, 13(2), 204.

Givoly, D., \& Palmon, D. 1982. Timeliness of Annual Earnings Announcements: Some Empirical Evidence. The Accounting Review, 57(3), 486-508.

Ghozali, Imam. 2016. Aplikasi Analisis Multivariate dengan Program SPSS, Semarang: Badan Penerbit Universitas Diponegoro

Handayani, A. P., \& Wirakusuma, M. G. 2013. Pengaruh Profitabilitas, Solvabilitas, Reputasi Kantor Akuntan Publik Pada Ketidaktepatwaktuan Publikasi Laporan Keuangan Perusahaan di BEI. E-Jurnal Akuntansi Universitas Udayana, 3(4), 472-487.

Hanum, Z. 2012. Pengaruh Profitabilitas terhadap Modal Kerja pada Perusahaan Makanan dan Minuman yang Terdaftar di Bursa Efek Indonesia. 
Hilmi, U., \& Ali, S. 2008. Analisis FaktorFaktor yang Mempengaruhi Ketepatan Waktu Penyampaian Laporan Keuangan: Studi Empiris pada Perusahaan-Perusahaan yang Terdaftar di BEJ Periode 2004-2006, (Pemakalah 1), 1-26.

Hossain, A. M., \& Taylor, P. J. 1998. An Examination of Audit Delay: Evidence from Pakistan An Examination of Audit Delay: Evidence from Pakistan An Examination of Audit Delay: Evidence from Pakistan.

Ikatan Akuntansi Indonesia. 2009. Pernyataan Standar Akuntansi Keuangan (PSAK) No. 1: Penyajian Laporan Keuangan, Jakarta: Ikatan Akuntansi Indonesia.

Jaswadi, J. 2004. Dampak Earnings Reporting Lags Terhadap Koefisien Respon Laba. The Indonesian Journal of Accounting Research, 7(3).

Kieso, Donald E., et al 2018. Intermediate Accounting, Edisi 3, United States of America: John Wiley \& Sons Inc.

Liputan 6. 2017, Belum Sampaikan Laporan Keuangan, BEI Suspensi 17 Saham Emiten, diakses pada 19 Oktober 2017, http://www.bisnisliputan6.com

Merdekawati, \& Regina. 2011. Fakultas Ekonomi Universitas Syiah Kuala Banda Aceh , 21-22 Juli 2011 Fakultas Ekonomi Universitas Syiah Kuala Banda Aceh , 21-22 Juli 2011. Simposium Nasional Akuntansi Xiv Aceh 2011, 1-25.

Prastiwi, E. D., Yuniarta, G. A., Ari, N., \& Darmawan, S. 2014. Ketepatan Waktu Pelaporan Keuangan, 2(1).

Rachmawati, S. 2008. Pengaruh Faktor Internal dan Eksternal Perusahaan
Terhadap Audit Delay dan Timeliness. Jurnal Akuntansi Dan Keuangan, 10(1), 1-10.

Respati, N. W. 2013. Faktor-Faktor yang Berpengaruh terhadap Ketepatan Waktu Pelaporan Keuangan: Studi Empiris di Bursa Efek Jakarta.

Republik Indonesia. 2012. Keputusan Ketua Bapepam dan LK Nomor: KEP431/BL/2012 tentang Penyampaian Laporan Tahunan Emiten atau Perusahaan Publik. Sekretariat Negara. Jakarta.

Republik Indonesia. 2016. Peraturan Otoritas Jasa Keuangan Nomor: 29/.04/2016 tentang Laporan Tahunan Emiten atau Perusahaan Publik. Sekretariat Negara. Jakarta.

Romney, Marshall B., Paul John Steinbart (2015), Accounting Information System, Edisi 13, England: Pearson Education Limited.

Sudarmadji, A. M., \& Sularto, L. 2007. Pengaruh Ukuran Perusahaan, Profitabilitas, Leverage, Dan Tipe Kepemilikan Perusahaan Terhadap Luas Voluntary Disclosure Laporan Keuangan Tahunan. Proceeding PESAT(Psikologi, Ekonomi, Sastra, Arsitek \& Sipil), 2, 53-61.

Suwardjono. 2005. Teori Akuntansi: Perekayasan Laporan Keuangan, Edisi 3, Yogyakarta: BPFE.

Wolk, Harry L., et al. 2001. Accounting Theory, Edisi 5, United States of America: South-Western College Publishing 


\begin{tabular}{l|r|r|r|r|}
\multicolumn{7}{c}{ LAMPIRAN } \\
Tabel 1 \\
Tabel Statistik Deskriptif \\
Descriptive Statistics \\
\hline
\end{tabular}

Sumber: Hasil Uji SPSS 20

Tabel 2

Tabel Frekuensi Timeliness

TIME

\begin{tabular}{|c|r|r|r|r|}
\hline & Frequency & Percent & Valid Percent & Cumulative Percent \\
\hline 0 & 18 & 6,9 & 6,9 & 6,9 \\
Valid 1 & 243 & 93,1 & 93,1 & 100,0 \\
Total & 261 & 100,0 & 100,0 & \\
\hline
\end{tabular}

Sumber: Hasil Uji SPSS 20

Tabel 3

Hasil Pooling Data

Variables in the Equation

\begin{tabular}{|c|c|c|c|c|c|c|c|}
\hline & & B & S.E. & Wald & $\mathrm{df}$ & Sig. & $\operatorname{Exp}(B)$ \\
\hline \multirow{12}{*}{ Step $1^{\mathrm{a}}$} & PRO & 5,094 & 12,077 & 0,178 & 1 & 0,673 & 163,063 \\
\hline & LEV & $-1,286$ & 1,183 & 1,181 & 1 & 0,277 & 0,276 \\
\hline & SIZE & $-0,294$ & 0,456 & 0,416 & 1 & 0,519 & 0,745 \\
\hline & DT1 & $-19,387$ & 15,786 & 1,508 & 1 & 0,219 & 0,215 \\
\hline & DT2 & $-9,646$ & 14,912 & 0,418 & 1 & 0,518 & 0,732 \\
\hline & PRO_DT1 & $-1,771$ & 12,439 & 0,020 & 1 & 0,887 & 0,170 \\
\hline & PRO_DT2 & 1,151 & 13,014 & 0,008 & 1 & 0,930 & 3,162 \\
\hline & LEV_DT1 & 0,964 & 1,425 & 0,458 & 1 & 0,499 & 2,622 \\
\hline & LEV_DT2 & 3,008 & 2,248 & 1,790 & 1 & 0,181 & 20,246 \\
\hline & SIZE_DT1 & 0,620 & 0,544 & 1,301 & 1 & 0,254 & 1,860 \\
\hline & SIZE_DT2 & 0,233 & 0,513 & 0,207 & 1 & 0,649 & 1,263 \\
\hline & Constant & 12,660 & 13,454 & 0,885 & 1 & 0,347 & 314853,495 \\
\hline
\end{tabular}

Sumber: Hasil Uji SPSS 20 
Tabel 4

Menilai Keseluruhan Model

Iteration History $\mathbf{a , b , c , c , d}$

\begin{tabular}{|c|c|c|c|c|c|c|}
\hline \multirow{2}{*}{\multicolumn{2}{|c|}{ Iteration }} & \multirow{2}{*}{$\begin{array}{c}-2 \text { Log } \\
\text { likelihood }\end{array}$} & \multicolumn{4}{|c|}{ Coefficients } \\
\hline & & & Constant & PRO & LEV & SIZE \\
\hline \multirow{6}{*}{ Step 1} & 1 & 145,708 & 1,220 & 1,373 & $-0,013$ & 0,016 \\
\hline & 2 & 127,849 & 1,197 & 3,236 & $-0,017$ & 0,036 \\
\hline & 3 & 126,105 & 0,834 & 4,577 & $-0,004$ & 0,056 \\
\hline & 4 & 126,068 & 0,689 & 4,818 & 0,001 & 0,063 \\
\hline & 5 & 126,068 & 0,682 & 4,824 & 0,001 & 0,063 \\
\hline & 6 & 126,068 & 0,682 & 4,824 & 0,001 & 0,063 \\
\hline
\end{tabular}

Sumber: Hasil Uji SPSS 20

Tabel 5

Koefisien Determinasi

Model Summary

\begin{tabular}{|l|r|r|r|}
\hline Step & -2 Log likelihood & Cox \& Snell R Square & Nagelkerke R Square \\
\hline 1 & $126,068^{\mathrm{a}}$ & 0,019 & 0,047 \\
\hline
\end{tabular}

Sumber: Hasil Uji SPSS 20

Tabel 6

Kelayakan Model Regresi

Hosmer and Lemeshow Test

\begin{tabular}{|l|r|r|r|}
\hline Step & Chi-square & df & Sig. \\
\hline 1 & 5,757 & 8 & 0,674 \\
\hline
\end{tabular}

Sumber: Hasil Uji SPSS 20

Tabel 7

Matriks Klasifikasi

Classification Table ${ }^{\mathrm{a}}$

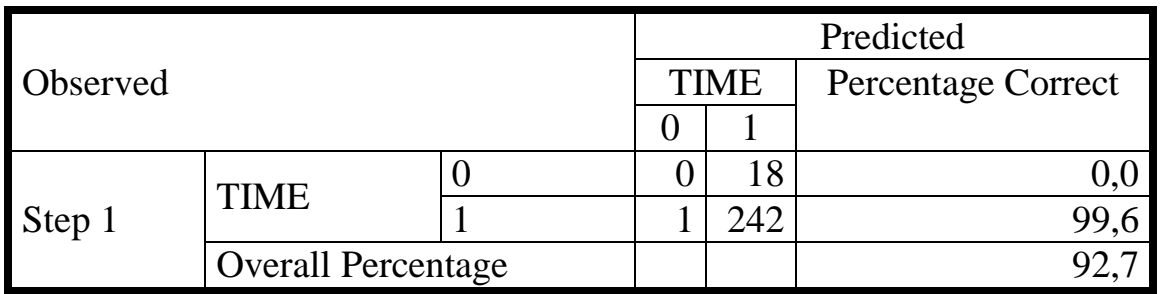

Sumber: Hasil Uji SPSS 20 
Tabel 8

Hasil Uji Regresi Logistik

Variables in the Equation

\begin{tabular}{|c|c|c|c|c|c|c|c|}
\hline & & B & S.E. & Wald & $\mathrm{df}$ & Sig. & $\operatorname{Exp}(B)$ \\
\hline \multirow{4}{*}{ Step $1^{\mathrm{a}}$} & PRO & 4,824 & 2,513 & 3,686 & 1 & 0,055 & 124,511 \\
\hline & LEV & 0,001 & 0,596 & 0,000 & 1 & 0,999 & 1,001 \\
\hline & SIZE & 0,063 & 0,163 & 0,149 & 1 & 0,700 & 1,065 \\
\hline & Constant & 0,682 & 4,569 & 0,022 & 1 & 0,881 & 1,979 \\
\hline
\end{tabular}

Sumber: Hasil Uji SPSS 20 